\begin{tabular}{|l|l|l||}
\hline \multicolumn{2}{|c|}{ PublisherInfo } \\
\hline \hline PublisherName & $:$ & BioMed Central \\
\hline \hline PublisherLocation & $:$ & London \\
\hline \hline PublisherImprintName & $:$ & BioMed Central \\
\hline \hline
\end{tabular}

Streptococcus pyogenes genome exposed

\begin{tabular}{||l|l|l||}
\hline \multicolumn{2}{|c|}{ ArticleInfo } \\
\hline \hline ArticleID & $:$ & 4055 \\
\hline \hline ArticleDOI & $:$ & $10.1186 /$ gb-spotlight-20010419-01 \\
\hline \hline ArticleCitationID & $:$ & spotlight-20010419-01 \\
\hline \hline ArticleSequenceNumber & $:$ & 126 \\
\hline \hline ArticleCategory & $:$ & Research news \\
\hline \hline ArticleFirstPage & $:$ & 1 \\
\hline \hline ArticleLastPage & $:$ & 2 \\
\hline \hline & & RegistrationDate : 2001-04-19 \\
ArticleHistory & $:$ & OnlineDate \\
\hline \hline ArticleCopyright & $:$ & BioMed Central Ltd2001 $04-19$ \\
\hline \hline ArticleGrants & $:$ & \\
\hline \hline ArticleContext & $:$ & 130592211 \\
\hline \hline
\end{tabular}




\section{Tudor Toma}

Email: ttoma@mail.dntis.ro

Streptococcus pyogenes is an exclusively human pathogen responsible for necrotizing fasciitis (flesheating disease), toxic shock syndrome, rheumatic fever and a host of other diseases - more than any other microorganism. In the April 10 Proceedings of the National Academy of Sciences, Joseph Ferretti and colleagues from the University of Oklahoma report on the completion of a five-year project to sequence the genome of $S$. pyogenes, and they explain their findings on the bacteria's virulence mechanisms.

Ferretti et al. determined the $S$. pyogenes genome sequence using the whole-genome shotgun approach. The genome contains 1,752 predicted protein-encoding genes of which more than 40 putative virulence-associated genes have been identified. Other genes so far identified encode proteins likely to be associated with microbial 'molecular mimicry' of host characteristics and implicated in diseases such as rheumatic fever and acute glomerulonephritis. Four different bacteriophage genomes were also detected, implying that bacteriophages are important in horizontal gene transfer and suggesting a possible mechanism for generating new bacterial strains with increased pathogenic potential (Proc Natl Acad Sci USA 2001, 98:4658-4663).

It is expected that understanding of the complete S. pyogenes genome will facilitate the development of more efficient drugs and the design of more specific vaccines.

\section{References}

1. Ferretti JJ, McShan WM, Ajdic D, Savic DJ, Savic G, Lyon K, Primeaux C, Sezate S, Suvorov AN, Kenton S: Complete genome sequence of an M1 strain of Streptococcus pyogenes. Proc Natl Acad Sci USA 2001, 98:4658-4663., [http://www.pnas.org/cgi/content/abstract/98/8/4658]

2. The University of Oklahoma, [http://www.ou.edu/]

This PDF file was created after publication. 